\title{
Depth-specific differences in growth of the reef sponge Callyspongia vaginalis: role of bottom-up effects
}

\author{
Geoffrey C. Trussell ${ }^{1, *}$, Michael P. Lesser ${ }^{2}$, Mark R. Patterson ${ }^{3}$, Salvatore J. Genovese ${ }^{1}$ \\ ${ }^{1}$ Marine Science Center, Northeastern University, 430 Nahant Road, Nahant, Massachusetts 01908, USA \\ ${ }^{2}$ Department of Zoology and Center for Marine Biology, University of New Hampshire, Durham, New Hampshire 03894, USA \\ ${ }^{3}$ Graduate School of Marine Science, Virginia Institute of Marine Science, College of William and Mary, Gloucester Point, \\ Virginia 23062-1346, USA
}

\begin{abstract}
Callyspongia vaginalis, a common reef sponge in the Florida Keys, USA, exhibits depthspecific differences in bioenergetics and growth that are a function of food availability. We measured several physiological parameters in situ to construct the bioenergetic budgets of sponges living in deep and shallow waters. Respiration rates were measured in a recirculating flow respirometer and pumping rates were measured by filming dye ejected from sponge oscula. In addition, inhalent and exhalent water sampled from around sponge colonies at both depths was analyzed using flow cytometry to quantify the concentration and clearance rates of picoplankton. These parameters were used to construct an energetic budget for sponges from each depth and revealed that the scope for growth was substantially greater for deep sponges compared to shallow sponges. The greater scope for growth of deep sponges is likely due to the greater abundance of picoplankton in the deep versus shallow habitat. Both naturally occurring sponges and those used in a reciprocal transplant experiment between 12 and 25 m exhibited significantly greater growth in the deep than the shallow habitat. Hence, bottom-up forcing in the form of increased food availability may be of principal importance to the growth and physiological ecology of suspension-feeding sponges.
\end{abstract}

KEY WORDS: Bioenergetics · Bottom-up forcing $\cdot$ Callyspongia vaginalis $\cdot$ Coral reefs $\cdot$ Internal waves $\cdot$ Food availability $\cdot$ Growth $\cdot$ Reef sponge

\section{INTRODUCTION}

Both top-down and bottom-up processes can influence the dynamics and structure of communities (Brooks \& Dodson 1965, Carpenter \& Kitchell 1993, Pace et al. 1999, Menge 2000). This conceptual dichotomy has fostered a prolific body of research exploring the importance of resource availability (bottom-up) versus predator or grazer (top-down) effects in a variety of habitats (Pace et al. 1999). In marine environments, however, research on these issues has been decidedly one-sided (Menge 1992, Menge et al. 1997), with an emphasis on top-down control of rocky intertidal community structure (Paine 1966, 1980, 2002, Dayton 1971, Estes \& Palmisano 1974, Lubchenco
1978, Menge 2000). Recently, the emphasis has shifted to examine the role of bottom-up processes acting either in concert with, or independent of, top-down processes (Menge et al. 1997, Leonard et al. 1998, Lotze et al. 2001, Nielsen 2001). In addition, ecologists have broadened the conventional definition of bottomup processes (nutrient supply) to include physical factors such as flow velocity (see Lesser et al. 1994, Leonard et al. 1998) or food delivery (Menge et al. 1997), with their subsequent effects on larval supply and organismal survivorship and physiology.

Next to corals, sponges are the most abundant macrofauna on coral reefs (Reiswig 1973, Wilkinson \& Cheshire 1990). The dominance of sponges on Caribbean reefs is particularly striking, with sponge 
biomass at depths between 15 and $20 \mathrm{~m}$ being 5 to 6 times greater than that found on similar Great Barrier Reefs (Wilkinson 1987). Over 80 sponge species have been recorded on reefs in the Florida Keys (Schmahl 1990), and close to 300 species occur on Bahamian reefs (Reed \& Pomponi 1997). In addition to creating structural complexity in reef habitats and providing shelter for numerous species, including fishes, brittle stars, and snapping shrimp, sponges strongly influence the overlying water column by filtering water during feeding (Reiswig 1973).

Despite the potential importance of sponges and other suspension-feeders to benthic-pelagic coupling (Gili \& Coma 1998) on coral reefs, many aspects of their biology remain poorly understood and, as a result, our overall understanding of energy transfer in these habitats remains incomplete. As active suspension-feeders, sponges may be particularly sensitive to variance in food availability and are thus a good model for examining the importance of bottom-up control in different environments. Pelagic productivity in tropical ecosystems is dominated by prokaryotes, and both photoautotrophic and heterotrophic picoplankton are important components of global productivity (Partensky et al. 1999, Ting et al. 2002). By virtue of their small size (1.0 $\mu \mathrm{m}$ or less), prokaryotic picoplankton are an ideal and significant food resource for active suspensionfeeding sponges (Pile 1997). Hence, sponges may provide a critical coupling between primary production and the benthos by converting planktonic carbon into sponge biomass (Pile et al. 1997).

This study focuses on habitat-specific differences in the growth of the sponge Callyspongia vaginalis, one of the dominant members of the sponge community in the Florida Keys. Unlike the photoautotrophic sponges typical of the Great Barrier Reef (Wilkinson 1983), this species acquires its food heterotrophically, and ambient food availability is thus likely to be more important to its growth. Here we use a bioenergetic approach to address (1) how depth-specific differences in food availability may influence scope for growth (the energy available for growth and reproduction after maintenance costs) in this species, and (2) whether depth-specific energy budget estimates are consistent with observed depth-specific differences in sponge growth.

\section{MATERIALS AND METHODS}

Study sites. All field manipulations and in situ measurements were conducted at a deep $(25 \mathrm{~m})$ and at a shallow site (12 m) on Conch Reef, Florida (24 $57.11^{\prime} \mathrm{N}$, $\left.80^{\circ} 27.57^{\prime} \mathrm{W}\right)$, USA, near the NOAA Aquarius underwater habitat. The deep site was located at the Northeast Mooring and the shallow site near the Fuel Mooring.
Food availability and consumption. At each depth, samples ( $\mathrm{N}=5$ per depth) of ambient seawater were collected near individual sponges approximately $5 \mathrm{~cm}$ away from their base and midway up one of their tubes. At the same time, we also sampled the ex-current flow by collecting water from $5 \mathrm{~cm}$ inside the osculum of the same tube. No measurements were made during obvious internal wave conditions (shimmering water, colder temperatures and reduced visibility) that can occur on Conch Reef (Leichter et al. 1996, 1998, 2003). Both ambient and ex-current samples were collected with $10 \mathrm{ml}$ Vacutainer ${ }^{\circledR}$ syringes. All samples were fixed at a final concentration of $0.5 \%$ electron microscopy grade glutaraldehyde in filtered $(0.2 \mu \mathrm{m})$ seawater and frozen at $-80^{\circ} \mathrm{C}$. Samples were sent frozen to the Flow Cytometry Facility at the Bigelow Laboratory for Ocean Sciences, where they were stored in liquid nitrogen until analysis, as described by Lesser et al. (1992).

Each sample was analyzed for cell abundances using a Becton Dickinson FACScan flow cytometer equipped with a $15 \mathrm{~mW}, 488 \mathrm{~nm}$, air-cooled Argon ion laser. Simultaneous measurements of forward light scatter (FSC, relative size), 90 light scatter (SSC), chlorophyll fluorescence (>650 nm), and phycoerythrin fluorescence (560 to $590 \mathrm{~nm}$ ) were made on all samples. Differentiation of cyanobacteria from prochlorophytes was based on the presence of phycoerythrin fluorescence. The photodiode (FSC) and photomultiplier (SSC) detectors were in log mode, providing 4 decades of response, and signal peak integrals were measured. The volume of sample analyzed by the FACScan was determined gravimetrically using an electronic balance, whereby each sample was weighed prior to analysis and immediately after the analysis was terminated. The difference in milligrams is proportional to the volume of sample analyzed in milliliters. All samples were run at either low $\left(\sim 20 \mu \mathrm{min}^{-1}\right)$ or high $\left(\sim 56 \mu \mathrm{l} \mathrm{min}{ }^{-1}\right)$ flow rates to insure that total particle counts did not exceed 1500 counts $\mathrm{s}^{-1}$. Cell abundance of the heterotrophic bacteria was determined using PicoGreen (Molecular Probes), a dsDNA-specific dye, which stains all prokaryotes (emission fluorescence 515 to $525 \mathrm{~nm}$ ). Subtraction of the photosynthethic cells from the total prokaryotes yielded the heterotrophic bacterial component of the community.

Filtration efficiency was calculated as 1 - (concentration of cells in the ex-current stream/ambient concentration of cells). The number of cells filtered $\mathrm{s}^{-1}$ was then computed by multiplying filtration efficiency (dimensionless $) \times$ volume flow rate pumped $\left(\mathrm{ml} \mathrm{s}^{-1}\right) \times$ ambient concentration (cells $\mathrm{ml}^{-1}$ ). All filtered cells were converted to carbon equivalents using the following conversions: heterotrophic bacteria, $20 \mathrm{fg} \mathrm{C} \mathrm{cell}^{-1}$ (Ducklow et al. 1993); Prochlorococcus spp., $53 \mathrm{fg} \mathrm{C} \mathrm{cell}^{-1}$ (Morel et al. 
1993); Synechococcus spp., $470 \mathrm{fg} \mathrm{C} \mathrm{cell}^{-1}$ (Campbell et al. 1994); eukaryotic cells (Verity et al. 1992), pg C =

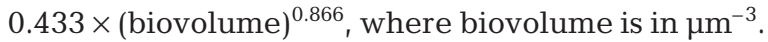

Carbon acquired $\mathrm{s}^{-1}$ was computed by multiplying number of cells filtered $\mathrm{s}^{-1}$ by that cell group's carbon equivalent per cell, or in the case of eukaryotic cells, was multiplied by the volume per cell and then multiplied by the carbon conversion for cell volume. Finally, carbon filtered $\mathrm{s}^{-1}$ was converted to $\mathrm{J} \mathrm{s}^{-1}$ using a conversion factor of $1 \mathrm{mg} \mathrm{C}=23.03 \mathrm{~J}$, assuming a respiratory quotient $(\mathrm{RQ})=1.0$, which is appropriate for ammonotelic animals (Parsons et al. 1984).

Sponge respirometry. An in situ metabolism system (Fig. 1) was deployed at $12 \mathrm{~m}$ depth in 1998 and $25 \mathrm{~m}$ depth in 1999. For logistical reasons it was not possible to obtain respirometry measurements simultaneously at shallow and deep sites. Nevertheless, we think our measurements are indicative of sponge performance at these 2 depths. The respirometry system consists of 6 metabolism chambers mounted on a PVC table. Each chamber is cylindrical $(15 \mathrm{~cm}$ internal diameter $x$ $20 \mathrm{~cm} \mathrm{H}$ ), has a volume of $3.7 \mathrm{l}$, and is fabricated from $6.5 \mathrm{~mm}$ UV transparent Plexiglas. All chambers are positioned over water-driven magnetic stirrers. A LI-COR U/W irradiance sensor (192 SA photosynthetically active radiation [PAR], 400 to $700 \mathrm{~nm}$ ) is mounted at the center of the chamber array. Each chamber is equipped with a polarographic oxygen sensor (Yellow Springs Instruments 5739) with temperature compensation (thermistor), a perforated plastic shelf to support the test organism(s), a magnetic stir bar, and an inlet and outlet port for flushing. The lid to each chamber is fitted with an O-ring. Hydraulic power to run the 6 magnetic stirrers and to provide periodic chamber flushing is provided by a submersible bilge pump (Rule $500 \mathrm{GPH}$, gallons $\left.\mathrm{h}^{-1}\left[1895 \mathrm{l} \mathrm{h}^{-1}\right]\right)$. The inlet turbulent jet has an entrance Reynolds number (Re) of $1.4 \times 10^{4}$ to ensure violent turbulent mixing. The chamber volume turnover time is $<60 \mathrm{~s}$ during flushing. A manifold for flushing and for stirring is connected to the pump by a single $1.9 \mathrm{~cm}$ Toro irrigation control valve.

Oxygen electrode polarization, Field Effect Transistor transimpedance preamplifiers for the oxygen electrodes, amplification and buffering for the electrode outputs, and pump and solenoid control are provided by a custom designed printed circuit, housed in an Ikelite U/W housing (No. 5910). This housing contains a LICOR datalogger (LI-1000) and LI-COR interface card (1000-05A) connected to the datalogger with a custom 36 conductor cable. All 6 oxygen electrodes, and the cable for a LI-COR U/W PAR irradiance sensor are attached via Brantner and Associates Sea-Con All-Wet ${ }^{\mathrm{TM}}$ $\mathrm{U} / \mathrm{W}$ connectors to the lid of this housing. Temperature compensated $\left(0\right.$ to $40^{\circ} \mathrm{C}$ ) oxygen concentrations can be measured from anoxic to supersaturated conditions, with an accuracy of $0.1 \mathrm{mg} \mathrm{l}^{-1}$ and a resolution of $0.01 \mathrm{mg} \mathrm{l}^{-1}$. PAR irradiance can be measured from 0 to $3000 \mu \mathrm{mol}$ quanta $\mathrm{m}^{-2} \mathrm{~s}^{-1}$, with a typical precision of $0.1 \mu \mathrm{mol}$ quanta $\mathrm{m}^{-2} \mathrm{~s}^{-1}$ and accuracy of $5 \%$ traceable to National Institute Standards and Technology.

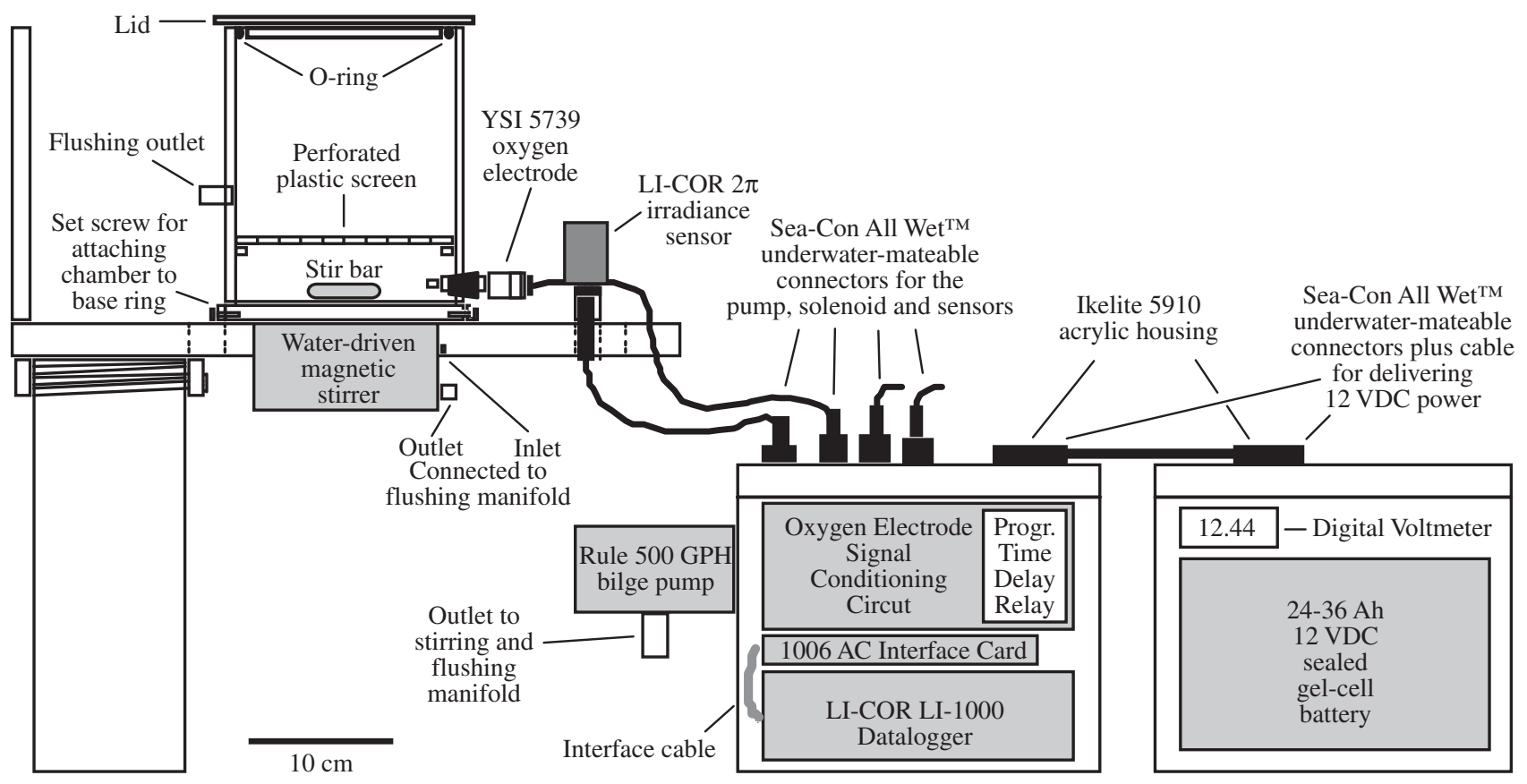

Fig. 1. Computer controlled respirometry system (only 1 of 6 chambers is shown). 500 GPH: bilge pump rate in gallons $\mathrm{h}^{-1}$ $\left(=1895 \mathrm{l} \mathrm{h}^{-1}\right)_{\text {i }}$ Ah: ampere-hour; VDC: volt direct current; Progr.: programmable 
A user programmable time-delay relay circuit controlled the flushing interval. We used a flushing interval of 30 min for our deployments. Brantner and Associates Sea-Con All-Wet ${ }^{\mathrm{TM}} \mathrm{U} / \mathrm{W}$ connectors allowed external, underwater-mateable connections between the solenoid, pump, and the battery power system housing. A split power supply ( $\pm 12 \mathrm{~V}$ direct current), consisting of 2 PowerSonic 1212 gel cells (1.2 amperehour [Ah] each), supplied the oxygen electrode circuitry. A second and third Ikelite (No. 5910) housing provided power to drive the pump and solenoid. The second housing was equipped with 2 Sea-Con AllWet $^{\mathrm{TM}} \mathrm{U} / \mathrm{W}$ connectors wired in parallel, allowing additional battery power systems to be daisy-chained for longer system deployments. The third housing in the daisy chain had a single Sea-Con connector. In each housing, an LCD DC (liquid crystal display, direct current) voltmeter (RadioShack) was connected to the gel cell battery (PowerSonic 12330, 33 Ah) via a magnetic burglar alarm switch. Tripping the reed switch with a magnet allowed a diver to read the battery voltage underwater. During normal use, the 2 battery power system housings (66 Ah) powered the stirring motors and allow chamber flushing for $24 \mathrm{~h}$.

To measure sponge respiration rates, a single tube (5 $\mathrm{cm}$ in length) cut from randomly selected sponge colonies at each depth was placed in each chamber. Any infaunal organisms (brittle stars, snapping shrimp) were removed from tubes before their placement in chambers. In addition, we only performed respiration measurements on sponges that contained no zoanthid Parazoanthus parasiticus colonies. Respiration rates were calculated by computing the time derivative $\left(\mathrm{mg} \mathrm{O}_{2} \mathrm{~min}^{-1}\right.$ ) of the raw oxygen measurements using the algorithm in Kaleidagraph 3.6. We used an oxycaloric conversion factor of $14.3 \mathrm{~J}\left(\mathrm{mg} \mathrm{O}_{2}{ }^{-1}\right)$ in all subsequent computations (Bradfield 1985).

Measurement of sponge pumping rates. During 1998, sponges were filmed in situ using Hi $8 \mathrm{~mm}$ analog video while they pumped sodium fluorescein dye at depths of 13 to 16 and 21 to $25 \mathrm{~m}$. Dye was released near the exterior wall of a tube at the base of sponges from a syringe operated by a SCUBA diver. Movement of sodium fluorescein dye over a known distance in known time was used to estimate pumping velocity, with a resolution of $0.1 \mathrm{~cm} \mathrm{~s}^{-1}$. Volume flow rate was estimated by multiplying pumping rate by cross-sectional area of the osculum. Each osculum was filmed from above immediately after dye ejection, and its area estimated to the nearest $1 \mathrm{~mm}^{2}$ using analysis tools in National Institute of Health Image (Version 1.61) on calibrated frame grabbed images. Volume flux was computed by multiplying ejection speed by the crosssectional area. This computation assumes plug flow (approximately uniform flow velocity across the tube's diameter) rather than laminar flow coming out of the tube. Careful examination of the dye fronts indicated that plug flow is a good approximation.

Scope for growth (SFG) approach. In addition to measuring growth directly, the energy available for growth can be determined from a bioenergetic budget. The measured physiological responses of sponges were converted to energy equivalents and used in the balanced energy equation to calculate SFG (Widdows \& Johnson, 1988). SFG has provided a quantitative basis for comparing the bioenergetics of bivalve mollusks (Bayne \& Widdows 1978, Wilbur \& Hilbish 1989, Clarke \& Griffiths 1990, Grant \& Cranford 1991, Lesser et al. 1994) and sea anemones (Zamer \& Shick 1987, Lesser et al. 1994) exposed to different physical environments and food regimes. SFG calculations provide a rapid and quantitative method of assessing the physiological, and therefore energetic, status of an animal under different environmental conditions. Production is expressed as $P=A-(R+U)$, where $P=$ somatic production, $R=$ respiratory energy expenses, and $U=$ energy lost as waste or excreta. The absorbed ration, $A$, is the product of total consumption of food energy and the absorption efficiency of energy from the food.

There are no available literature values of absorption efficiencies for sponges, and estimations are not technically feasible, largely because members of this phylum are cellular grade organisms. For these calculations we assumed equivalent absorption efficiencies. Measured rates of ammonia production during the respiration experiments were low $(<1 \%)$ and revealed no significant differences between depths (M. P. Lesser unpubl. data). Because ammonia production contributed so little to the overall energetic budget, costs associated with excretion were not used in the calculation of SFG.

Natural growth of shallow and deep sponges. In October 1998, 20 sponge colonies at each depth were monitored to record natural growth. We inserted numerically coded Floy Tags ${ }^{\mathrm{TM}}$ through the wall of 3 tubes within each colony $1 \mathrm{~cm}$ from the leading edge of each tube. A small tagging gun was pushed through the wall of each tube and a Floy Tag ${ }^{\mathrm{TM}}$ was inserted. A T-bar anchored each tag on the interior of each tube. We visited all colonies 1 yr later and recorded growth by measuring the total linear extension of each tube. In all cases, new growth around the perimeter of each tube was highly symmetrical, in terms of both linear extension and tube thickness, suggesting that tagging position on the tube did not influence our results. Although sponge growth can occur in multiple dimensions, this approach provides a sound general assessment of sponge growth while being minimally invasive. Moreover, our results using this approach agree nicely with the biomass approach used in the reciprocal transplant experiment (see next subsection). 
Reciprocal transplant experiment between shallow and deep sites. To further examine whether depth-specific differences in food abundance promote depthspecific differences in sponge growth, we performed a reciprocal transplant experiment between a shallow $(12 \mathrm{~m})$ and a deep $(25 \mathrm{~m})$ site on Conch Reef in October 1998. We cut 2 tubes $(5 \mathrm{~cm}$ length each) from each of 15 randomly selected Callyspongia vaginalis colonies at each depth. One tube remained at its native site while the other was transplanted. We utilized this approach to ensure that any potential genetic variation in sponge growth within each source population was similar for each depth. There were 4 transplant groups: (1) shallow to shallow (SS); (2) shallow to deep (SD); (3) deep to deep (DD); (4) deep to shallow (DS).

Before transplanting in the field, all sponge tubes were returned to the laboratory and, while immersed in seawater, weighed $( \pm 0.001 \mathrm{~g})$ with a digital analytical balance (Mettler PG503S) to measure total initial biomass. Sponges remained completely submerged during this procedure. We used buoyant weight as our estimate of biomass because exposure to air may adversely affect the pumping ability and overall health of sponges once they are returned to the field. In addition, growth in terms of biomass integrates all possible types of growth (compared to linear extension) and thus provides the most complete picture of actual performance. After measurements of initial biomass, sponges were transplanted to small racks anchored to the reef pavement with large nails and nylon rope lanyards. Tubes were individually attached to each rack by inserting a cable tie through each side of their base and tying them to 2 additional cable tie loops on the PVC rack.

No adverse effects appeared to result from this protocol, since at the end of the experiment all sponges had managed to adhere directly to the PVC racks themselves. Indeed, some sponges grew to such an extent that they were able to re-attach to the reef itself. Sponges remained on their transplant racks until October $1999(\sim 1 \mathrm{yr})$, after which remaining sponges were recovered and their final buoyant weight recorded. Sponge growth in terms of biomass (final dry weight initial dry weight) was the response variable in our analyses. After recording final buoyant weight, all sponges were dried at $60^{\circ} \mathrm{C}$ for $48 \mathrm{~h}$ and weighed in air to obtain total dry biomass. These data allowed us to generate a regression of dry weight $(Y)$ as a function of buoyant weight $(X)$. The strong relationship between these 2 variables $\left(p<0.0001 ; R^{2}=0.72\right)$ allowed us to use this regression (dry weight $=3.29804 \times$ buoyant weight +1.11435 ) to estimate the initial dry weight of sponges from their initial buoyant weight. This equation was also used to estimate dry weight from the buoyant weight of sponges used in our respirometry measurements (see earlier subsection).
Statistical analyses. Data characterizing the food available to, and energy acquired by, sponges were analyzed with 2-way analysis of variance (ANOVA). Data for each year were analyzed separately. We first analyzed differences in the total amount of food available and energy acquired with a 1-way ANOVA that considered depth as a fixed effect. This analysis provided a picture of absolute differences among depths. A second analysis considered depth (shallow, deep) and food type (cyanobacteria, heterotrophic bacteria, eukaryotic phytoplankton and prochlorophytes) as fixed effects. This analysis allowed us to more explicitly examine how depth-specific differences in the abundance of certain food types may ultimately affect the total amount of energy acquired by sponges.

Respirometry data were analyzed with 1-way ANCOVA that considered depth as a fixed effect and dry sponge biomass as the covariate. These data were also analyzed with a 1-way ANOVA to provide unadjusted least-square means for comparison with means from our analysis of energy acquisition (see 'Results').

Data from the natural growth experiment were analyzed with a 1-way ANOVA with sponge colony as a random factor nested within depth. This approach considers each colony, rather than each tube, as the experimental unit. Data from the reciprocal transplant experiment were analyzed with a 2-way ANCOVA that treated source population and depth as fixed effects. Initial dry mass (determined as described in foregoing subsection) was used as the covariate to adjust for the potential effect of initial biomass on subsequent growth, and total change in dry biomass (final - initial values) was our response variable. ANCOVA revealed that the slopes of regression lines for each experimental combination were homogeneous $(p=0.58)$, thus allowing comparison of adjusted mean sponge growth (Sokal \& Rohlf 1981).

All analyses were conducted using JMP software (Version 3.1, SAS Institute). Residuals of all data were examined to determine whether they conformed to the assumptions of ANOVA. When assumptions were not met, data were $\log _{(10)}$-transformed to correct the problem, which was usually heteroscedastic variances. All post hoc comparisons were performed using the linear contrast feature of JMP (1995). We used a significance of level of 0.05 for post hoc tests.

\section{RESULTS}

\section{Food availability and consumption}

Our 1-way ANOVA indicated that in 1998 the total amount of food available to sponges was significantly greater at the deep than at the shallow site (ANOVA: 
$F_{1,18}=34.34, \mathrm{p}<0.0001 ;$ Fig. 2). The 2-way ANOVA on 1998 data revealed no significant depth effect (ANOVA: $F_{1,72}=2.70, \mathrm{p}=0.1050$ ), but significant differences in the abundance of different food types (ANOVA: $F_{3,72}=14453.17, \mathrm{p}<0.0001$ ). In addition, there was a highly significant 'Depth $\times$ Food Type' interaction (ANOVA: $F_{3,72}=54.54, \mathrm{p}<0.0001$ ) caused by depth-dependent reversals in the abundance of cyanobacteria and prochlorophytes.

Within-site comparisons revealed that heterotrophic bacteria were the most abundant food type at both depths (linear contrasts, both $p<0.0001$ ). At the shallow site, the rank order of abundance for each food type after heterotrophic bacteria was cyanobacteria, followed by prochlorophytes, and then phytoplankton (linear contrasts, all $\mathrm{p}<0.0001$ ). In contrast, at the deep

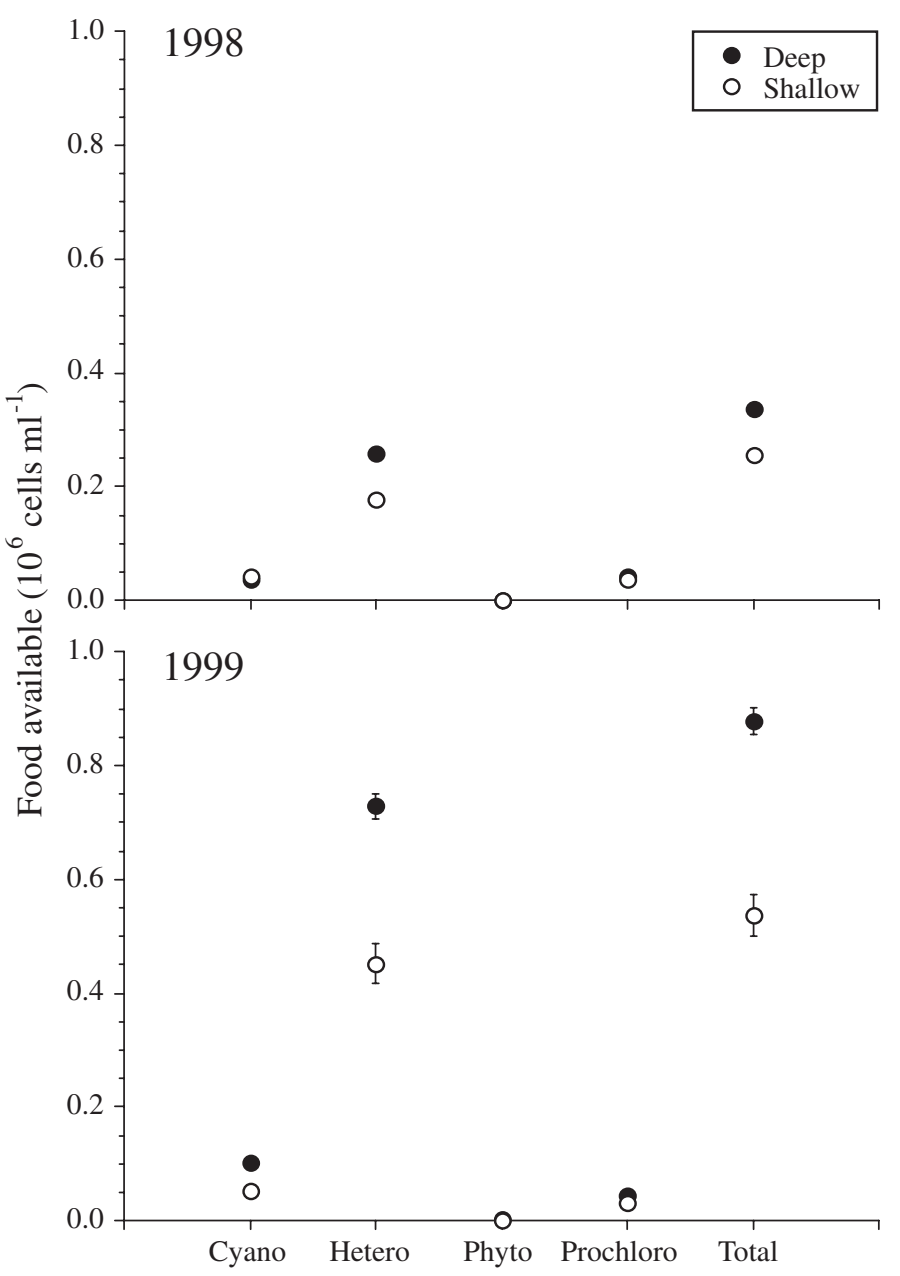

Fig. 2. Callyspongia vaginalis. Mean $( \pm \mathrm{SE})$ food available at shallow and deep sites on Conch Reef, Florida Keys, for 1998 and 1999. In some cases, error bars are smaller than symbols. See 'Results; Food availability and consumption' for details. Cyano: cyanobacteria; Hetero: heterotrophic bacteria; Phyto: phytoplankton; Prochloro: prochlorophytes site the rank order of abundance for each food type after heterotrophic bacteria was prochlorophytes, followed by cyanobacteria, and then phytoplankton (linear contrasts, all $\mathrm{p}<0.0001$ ). Comparisons between depths revealed that the deep site had significantly more heterotrophic bacteria (linear contrast, $\mathrm{p}<0.0001$ ) and prochlorophytes (linear contrast, $\mathrm{p}=0.0018$ ) while the shallow site had significantly more cyanobacteria (linear contrast, $\mathrm{p}=0.003$ ) and phytoplankton (linear contrast, $\mathrm{p}<0.0001$ ).

In 1999, habitat-specific differences in food availability were stronger and more consistent than in 1998. The total amount of food was significantly greater at the deep versus the shallow site (ANOVA: $F_{1,8}=43.97, \mathrm{p}<0.0001$; Fig. 2). Our 2-way analyses revealed significant differences among depths (ANOVA: $F_{1,32}=303.52, \mathrm{p}<0.0001$ ) and food types (ANOVA: $F_{3,32}=5077.80, \mathrm{p}<0.0001$ ) as well as a significant 'Depth $\times$ Food Type' interaction (ANOVA: $F_{3,32}=11.36, \mathrm{p}<0.0001$ ).

Within-site comparisons revealed the same rank order in the abundance of different food types for each depth. At both depths, heterotrophic bacteria were the most abundant food type, followed by cyanobacteria, prochlorophytes and then phytoplankton (linear contrasts, all $\mathrm{p}<0.0001)$. In addition, comparisons between depths revealed that the deep site had significantly more of each food type than the shallow site (linear contrasts, all $\mathrm{p}<0.0001$ ).

\section{Energy acquisition}

In both 1998 (ANOVA: $F_{1,72}=48.32, \mathrm{p}<0.0001$ ) and 1999 (ANOVA: $F_{1,32}=95.94, \mathrm{p}<0.0001$ ), deep sponges acquired significantly more total energy than shallow sponges (1049 $\mathrm{J} \mathrm{d}^{-1}$ in 1998 and $1569 \mathrm{~J} \mathrm{~d}^{-1}$ in 1999) (Fig. 3). In contrast shallow sponges acquired $926 \mathrm{~J} \mathrm{~d}^{-1}$ in 1998 and $824 \mathrm{~J} \mathrm{~d}^{-1}$ in 1999. There were also significant differences in the amount of energy provided by each food type in both 1998 (ANOVA: $F_{3,72}=34.34, \mathrm{p}<0.0001$ ) and 1999 (ANOVA: $F_{3,32}=$ 34.34, $\mathrm{p}<0.0001$ ). Finally, in both 1998 (ANOVA: $F_{1,72}=25.48, \mathrm{p}<0.0001$ ) and 1999 (ANOVA: $F_{3,32}=$ 16.57, $\mathrm{p}<0.0001$ ), there was a significant 'Depth $\times$ Food Type' interaction.

The percentage of total energy contributed by each food type is presented in Table 1. In general, prochlorophytes and heterotrophic bacteria were the primary sources of energy; in both years deep sponges acquired significantly more energy from these food types than shallow sponges (Fig. 3). The amount of energy acquired by deep and shallow sponges from cyanobacteria was not different in 1998, but in 1999 cyanobacteria contributed signifi- 


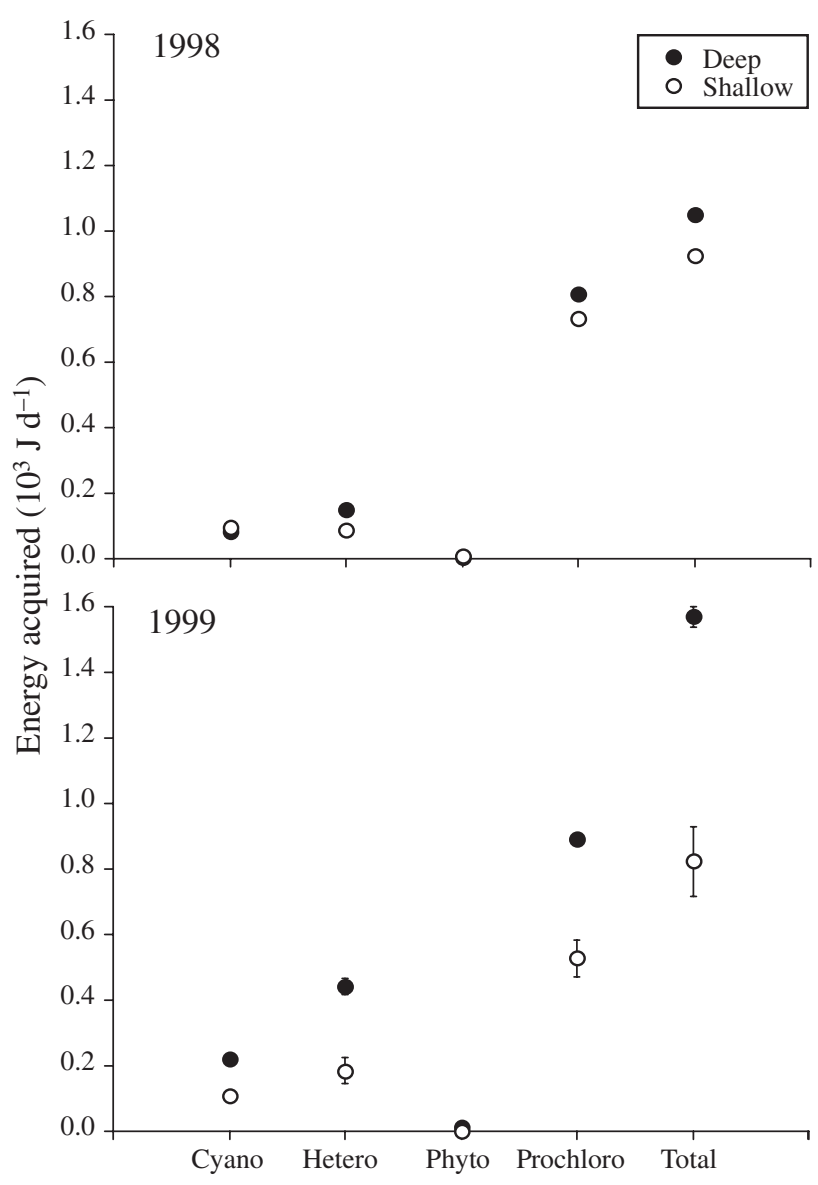

Fig. 3. Callyspongia vaginalis. Mean $( \pm \mathrm{SE})$ energy acquired by shallow and deep sponges on Conch Reef in 1998 and 1999. In some cases, error bars are smaller than symbols. See 'Results; Energy acquisition' and Table 1 for more details and breakdown of energy provided by different food groups

Table 1. Callyspongia vaginalis. Total energy (\%) contributed by each food type in shallow and deep water sponges in 1998 and 1999. Absolute energy quantity $\left(\mathrm{J} \mathrm{d}^{-1}\right)$ actually acquired is shown in Fig. 3. Values sharing the same superscript letter within each site and year are not significantly different (post hoc tests, $\mathrm{p}<0.005$ )

\begin{tabular}{|lrccc|}
\hline Depth & $\begin{array}{c}\text { Cyano- } \\
\text { bacteria }\end{array}$ & $\begin{array}{c}\text { Heterotrophic } \\
\text { bacteria }\end{array}$ & $\begin{array}{c}\text { Phyto- } \\
\text { plankton }\end{array}$ & $\begin{array}{c}\text { Prochloro- } \\
\text { phytes }\end{array}$ \\
\hline $\mathbf{1 9 9 8}$ & & & & \\
Shallow & $10.4^{\mathrm{b}}$ & $9.7^{\mathrm{b}}$ & $0.8^{\mathrm{c}}$ & $79.2^{\mathrm{a}}$ \\
$\begin{array}{l}\text { Deep } \\
\mathbf{1 9 9 9}\end{array}$ & $8.0^{\mathrm{c}}$ & $14.3^{\mathrm{b}}$ & $0.5^{\mathrm{d}}$ & $77.2^{\mathrm{a}}$ \\
Shallow & $13.0^{\mathrm{b}}$ & $22.5^{\mathrm{b}}$ & $0.3^{\mathrm{c}}$ & $64.1^{\mathrm{a}}$ \\
Deep & $14.2^{\mathrm{c}}$ & $28.2^{\mathrm{b}}$ & $0.9^{\mathrm{d}}$ & $56.8^{\mathrm{a}}$ \\
\hline
\end{tabular}

cantly more energy to deep than to shallow sponges. Energetically, phytoplankton represented a small fraction of the total budget and there were no differences between shallow and deep sponges in either year (Fig. 3).

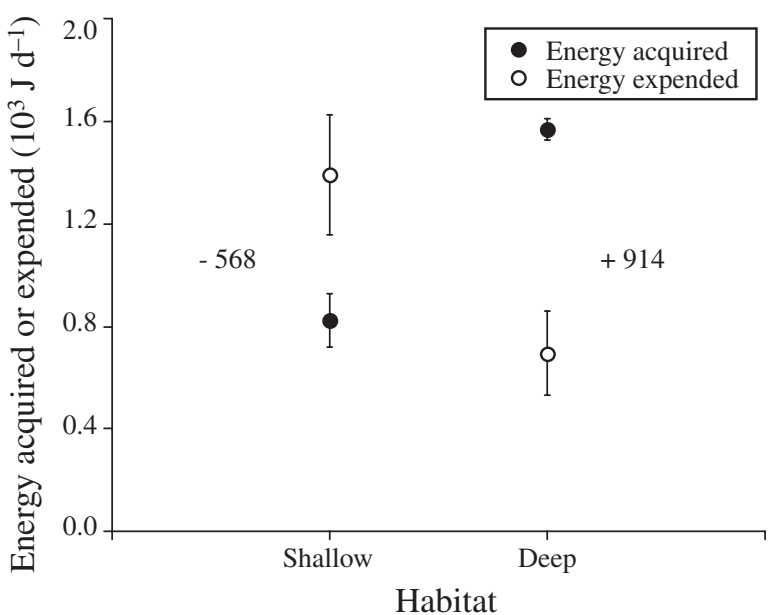

Fig. 4. Callyspongia vaginalis. Energy budget expressing total amount of energy acquired and expended by shallow and deep sponges on Conch Reef. Budget used food availability and respiration data obtained in 1999 because we did not have respiration data for deep sponges in 1998; nevertheless, use of food availability data from 1998 with respiration data from 1999 provided very similar results. In some cases, error bars are smaller than symbols. Numeric values next to symbols reflect the net energy expended by shallow sponges and the net energy acquired by deep sponges

\section{Energy expended}

The ANCOVA on sponge respirometry data revealed homogeneous slopes (ANCOVA: $F_{1,5}=0.01$, $\mathrm{p}=0.9243$ ) and this term was therefore pooled (Sokal \& Rohlf 1981). Our pooled analysis revealed that shallow sponges expended more energy per day than deep sponges (ANCOVA: $F_{1,6}=6.41, p=0.0446$ ). The covariate, sponge biomass, was not significant, so we also ran an ANOVA on these data to produce means that were not adjusted for biomass and thus were dimensionally equivalent to our estimates of energy acquired (i.e. $\mathrm{J} \mathrm{d}^{-1}$ ). This analysis indicates that shallow sponges expended more energy than deep sponges (ANOVA: $F_{1,7}=5.36, \mathrm{p}=0.0538$ ).

These increased respiratory costs coupled with reduced energy acquisition suggest that shallow sponges have less SFG than deep sponges. Calculation of energy budgets for 1998 and 1999 indicate that shallow sponges have an energy deficit of 465 and $568 \mathrm{~J}$ $\mathrm{d}^{-1}$, whereas deep sponges have a surplus of 393 and $914 \mathrm{~J} \mathrm{~d}^{-1}$ (Fig. 4) during the snapshot in time for which these data were collected.

\section{Natural sponge growth and reciprocal transplant experiment}

After $1 \mathrm{yr}$, natural sponge growth in terms of linear tube extension revealed that deep sponges grew sig- 


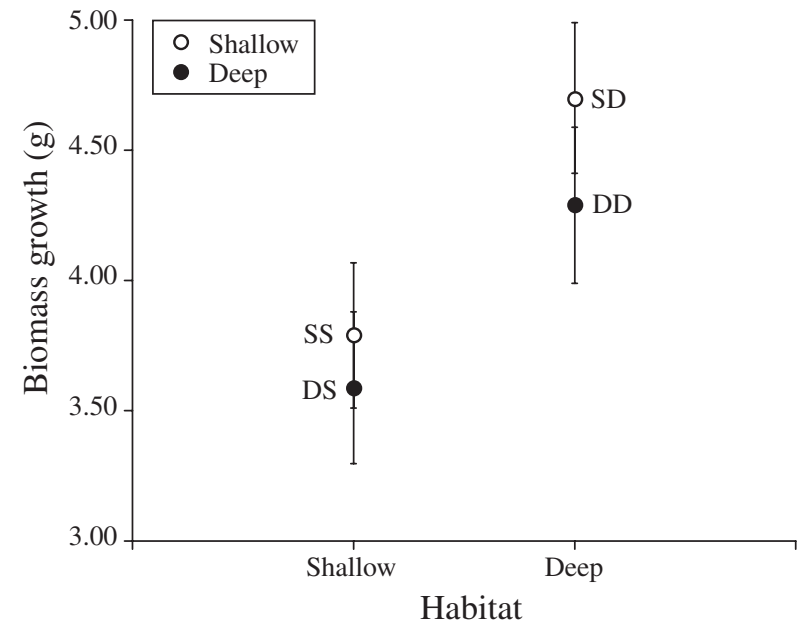

Fig. 5. Callyspongia vaginalis. Mean $( \pm \mathrm{SE})$ growth after $\sim 1 \mathrm{yr}$ of sponges reciprocally transplanted between a shallow and a deep site on Conch Reef. SS: shallow to shallow; SD: shallow to deep; DD: deep to deep; DS: deep to shallow. Regardless of origin, sponges raised at the deep site grew to a significantly greater extent than those raised at the shallow site (see 'Results; Natural sponge growth and reciprocal transplant experiment')

nificantly more $(20 \%)$ in terms of linear tube extension than shallow sponges (ANOVA: $F_{1,2}=4.68 ; \mathrm{p}=0.0327$ ). Data from the reciprocal transplant experiment were consistent with our natural growth data and predicted depth-specific differences in sponge SFG (Fig. 5). Sponges from both the shallow and deep population grew significantly more at the deep site than at the shallow site (ANOVA: $F_{1,34}=8.13 ; \mathrm{p}=0.0074$ ). There were no significant population-specific differences in sponge growth (ANOVA: $F_{1,34}=1.17 ; \mathrm{p}=0.2863$ ), and shallow and deep sponges responded similarly to both depths, as evidenced by a non-significant 'Source Population $\times$ Depth' interaction (ANOVA: $F_{1,34}=0.36$; $\mathrm{p}=0.5528)$.

\section{DISCUSSION}

The results of this study suggest that depth-specific differences in food supply can strongly influence SFG and realized growth in Callyspongia vaginalis. Compared to the shallow site, consistently more of the total food at the deep site was largely provided (85 to $95 \%$ ) by heterotrophic bacteria and prochlorophytes (Fig. 2). The depth-specific patterns in food availability translated into significant differences in energy acquisition, with deep sponges acquiring $\sim 1025$ to $1550 \mathrm{~J} \mathrm{~d}^{-1}$ and shallow sponges only $\sim 800$ to $925 \mathrm{~J} \mathrm{~d}^{-1}$. This pattern in energy acquisition was probably tied to differences in food availability, since the pumping rates of sponges did not differ among depths (M. R. Patterson, M. P.
Lesser \& G. C. Trussell unpubl. data). Similar depthspecific differences in food availability, feeding and growth have also been observed for sponges on Belizean and Bahamian reefs, and are independent of depth-specific differences in sponge size (Lesser 2006).

Our SFG calculations based on snapshots of respiratory costs, food availability and pumping activity indicate that the shallow site is less energetically favorable than the deep site because, in addition to lower food availability, shallow sponges had higher respiratory costs. It is unlikely that differences in respiratory costs are temperature related, because mean $( \pm S D)$ water temperatures during respiration runs at each site were quite similar (shallow site: $28.22 \pm 0.24^{\circ} \mathrm{C}$, deep site: $27.30 \pm 0.13^{\circ} \mathrm{C}$ ). Our energy budget indicates that deep sponges have an energetic surplus of $\sim 393$ to $914 \mathrm{~J} \mathrm{~d}^{-1}$, whereas shallow sponges have a deficit of $\sim 465$ to $568 \mathrm{~J} \mathrm{~d}^{-1}$ (Fig. 4). Hence, shallow sponges appear to be at an energetic disadvantage compared to deeper conspecifics.

The hypothesis that deep-water habitats represent a better growth environment than shallow-water habitats is supported by patterns of growth observed in natural sponge populations and in sponges reciprocally transplanted between the 2 habitats. Natural sponge growth (in terms of linear extension of their tubes) was $20 \%$ greater at the deep than at the shallow site. Moreover, when raised at the deep site, both shallow and deep sponges grew to a significantly greater extent (in terms of total biomass) than their counterparts maintained at the shallow site (Fig. 5). The greater growth at the deep site was statistically similar for sponges from both source populations, suggesting that shallow and deep sponges are not genetically differentiated in their response to different growth environments. Compared to the shallow site, deep sponges grew $19 \%$ more in their native habitat, whereas transplanted shallow sponges grew $24 \%$ more. These growth differences among transplant sites occurred despite their being in relatively close horizontal proximity (scale of 100s of meters) to each other.

Benthic suspension-feeding communities are thought to be central to bottom-up coupling and energy transfer from the plankton to the benthos (Gili \& Coma 1998). For example, Lesser et al. (1994) suggested that increased coupling between the productivity of the overlying water column and the benthic community in the Gulf of Maine was mediated by differences in the rates of water flow between offshore and coastal environments as well as organismal feeding mode. They found that offshore populations of the passive suspension-feeding anemone Metridium senile exhibited an energetic advantage and higher growth rates than coastal populations, whereas in coastal environments the active suspension-feeding horse mussel Modiolus 
modiolus had a similar energetic advantage and higher growth rates than at offshore sites. We suggest that depth-specific differences in food availability have a bottom-up effect on sponge bioenergetics and growth and that the sponge community plays a central role in benthic-pelagic coupling on Conch Reef.

Could other processes determine the observed growth patterns in these sponge populations? On Caribbean reefs, predation by spongivorous fishes is often cited as a major determinant of sponge community structure (Pawlik 1997, 1998, Wulff 1997). On Conch Reef, fishes known to consume sponges are abundant at the depths (12 to $25 \mathrm{~m}$ ) at which we assessed sponge growth and feeding, but we observed no evidence of predation, such as the removal of significant biomass, during our study. Callyspongia vaginalis is not chemically or structurally defended against predation by fishes (Chanas \& Pawlik 1995, Pawlik et al. 1995) and is also a species of poor nutritional quality (Chanas \& Pawlick 1995). Thus, this species is an available, albeit poor, nutritional source for spongivorous fishes on reefs. Indeed, despite these poor defenses, $C$. vaginalis is one of the most abundant sponges on Caribbean reefs (Pawlik et al. 1995). Moreover, a frequently cited paper suggesting the potential for fish predation on $C$. vaginalis concludes that there is no strong evidence that such predation is important to the distribution of this species (Randall \& Hartman 1968). Lastly, a multifactorial study by Duffy \& Paul (1992) found that sponge nutritional quality, not chemical defenses, was the major factor determining whether fish consumed sponges.

It is also possible that depth-specific differences in food availability may result from depth-specific differences in sponge biomass. Because sponges filter nearly twice their biomass every minute, increased sponge biomass at shallow depths should increase the rate and amount of picoplankton removed from the water column. However, in a thorough study of the abundance of 80 sponge species in the Florida Keys, Schmahl (1990) found that most species (including Callyspongia vaginalis) exhibited increased abundance with increasing depth. Thus, the reduced food availability we observed at shallow depths is not consistent with sponge abundance in the Florida Keys. Instead, one would expect food limitation to be most important in deeper waters where sponges are more abundant.

Marine ecologists are increasingly appreciative of the importance of bottom-up forcing to benthic communities and have identified the role that physical oceanographic factors such as upwelling may play in this process (Menge et al. 1997). Our study suggests that bottom-up processes may be important to sponge bioenergetics and energy transfer on Conch Reef, but more work is needed to identify the biological and/or physical processes responsible for increased food availability at deeper depths. Other studies have indicated that internal wave activity on Conch Reef (Leichter et al. 1996, 1998, 2003) and elsewhere (Witman et al. 1993, 2004) may enhance food availability at deeper depths during the stratified season. However, because our measurements were performed during non-internal wave conditions, this phenomenon probably plays an ancillary role in producing depth-specific differences in food availability.

Acknowledgements. We thank the staff of the National Undersea Research Center at the University of North Carolina Wilmington, Key Largo, for superb day boat and saturation diving support that made this study possible. Steven Miller provided ammonia analyses and access to a Mettler balance. A special thanks to Terri Cucci for conducting the flow cytometry analyses. Greg Shellenbarger and Tom Eldridge provided diving support. We also thank J. Pawlik for many helpful comments on a previous version of this paper. This work was supported by a grant from the National Undersea Research Program (University of North Carolina, Wilmington) and the College of William and Mary.

\section{LITERATURE CITED}

Bayne BL, Widdows J (1978) The physiological ecology of two populations of Mytilus edulis L. Oecologia 37:137-162

Bradfield AE (1985) Laboratory studies of energy budgets. In: Tyler P, Calow P (eds) Fish energetics: new perspectives. Croom Helm, London, p 257-281

Brooks JL, Dodson SI (1965) Predation, body size, and the composition of plankton. Science 150:28-35

Campbell L, Nolla HZ, Vaulot D (1994) The importance of Prochlorococcus to community structure in the central North Pacific Ocean. Limnol Oceanogr 39:954-960

Carpenter SR, Kitchell JF (1993) The trophic cascade in lakes. Cambridge University Press, London

Chanas B, Pawlik JR (1995) Defenses of Caribbean sponges against predatory reef fish. II. Spicules, tissue toughness, and nutritional quality. Mar Ecol Prog Ser 127:195-211

Clarke BC, Griffiths CL (1990) Ecological energetics of mussels Choromytilus meridionalis under simulated rocky pool conditions. J Exp Mar Biol Ecol 137:63-77

Dayton PK (1971) Competition, disturbance and community organization: the provision and subsequent utilization of space in a rocky intertidal community. Ecol Monogr 41: 351-389

Ducklow HW, Kirchman DL, Quinby HL, Carlson CA, Dam HG (1993) Stocks and dynamics of bacterioplankton carbon during the spring bloom in the eastern North Atlantic Ocean. Deep-Sea Res 40:245-263

Duffy JE, Paul VJ (1992) Prey nutritional quality and the effectiveness of chemical defenses against tropical reef fishes. Oecologia 90:333-339

Estes JA, Palmisano JF (1974) Sea otters: their role in structuring nearshore communities. Science 185:1058-1060

Gili JF, Coma R (1998) Benthic suspension feeders: their paramount role in littoral marine food webs. Trends Ecol Evol 13:316-321

Grant J, Cranford PJ (1991) Carbon and nitrogen scope for growth as a function of diet in the sea scallop Placopecten magellanicus. J Mar Biol Assoc UK 71:437-450 
JMP (1995) Statistics and graphics guide, Version 3.1. SAS Institute, Cary, NC

Leichter JJ, Wing SR, Miller SL, Denny MW (1996) Pulsed delivery of subthermocline water to Conch Reef (Florida Keys) by internal tidal bores. Limnol Oceanogr 41: 1490-1501

Leichter JJ, Shellenbarger G, Genovese SJ, Wing SR (1998) Breaking internal waves on a Florida (USA) coral reef: a plankton pump at work? Mar Ecol Prog Ser 166:83-97

Leichter JJ, Stewart HL, Miller SL (2003) Episodic nutrient transport to Florida coral reefs. Limnol Oceanogr 48: 1394-1407

Leonard GH, Levine JM, Schmidt PR, Bertness MD (1998) Flow driven variation in intertidal community structure in a Maine estuary. Ecology 79:1395-1411

Lesser MP (2006) Benthic-pelagic coupling on coral reefs: feeding and growth of Caribbean sponges. J Exp Mar Biol Ecol 328:277-288

Lesser MP, Shunway SE, Cucci T, Smith J, (1992) Impact of fouling organisms on mussel rope culture: interspecific competition among suspension-feeding invertebrates. J Exp Mar Biol Ecol 165:91-102

Lesser MP, Witman JD, Sebens KP (1994) Effects of flow and seston availability on scope for growth of benthic suspension-feeding invertebrates from the Gulf of Maine. Biol Bull (Woods Hole) 187:319-335

Lotze HK, Worm B, Sommer U (2001) Strong bottom-up and top-down control of early life stages of macroalgae. Limnol Oceanogr 46:749-757

Lubchenco J (1978) Plant species diversity in a marine intertidal community: importance of herbivore food preference and algal competitive abilities. Am Nat 112: $23-29$

Menge BA (1992) Community regulation: under what conditions are bottom-up factors important on rocky shores? Ecology 73:755-765

Menge BA (2000) Top-down and bottom-up community regulation in marine rocky intertidal habitats. J Exp Mar Biol Ecol 250:257-289

Menge BA, Daley BA, Wheeler PA, Dahlhoff E, Sanford E, Strub PT (1997) Benthic-pelagic links and rocky intertidal communities: bottom-up effects on top-down control? Proc Natl Acad Sci USA 94:14530-14535

Morel A, Ahn YH, Partensky F, Vaulot D, Claustre H (1993) Prochlorococcus and Synechococcus: a comparative study of their optical properties in relation to their size and pigmentation. J Mar Res 51:617-649

Nielsen KJ (2001) Bottom-up and top-down forces in tide pools: test of a food chain model in an intertidal community. Ecol Monogr 71:187-217

Pace ML, Cole JJ, Carpenter SR, Kitchell JF (1999) Trophic cascades revealed in diverse ecosystems. Trends Ecol Evol $14: 483-488$

Paine RT (1966) Food web complexity and species diversity. Am Nat 100:65-75

Paine RT (1980) Food webs: linkage, interaction strength and community infrastructure. J Anim Ecol 49:667-685

Paine RT (2002) Trophic control of production in a rocky intertidal community. Science 296:736-739

Parsons TR, Takahashi M, Hargrave B (1984) Biological oceanographic processes, 3rd edn. Pergamon Press, Tarrytown, NY

Partensky F, Hess WR, Vaulot D (1999) Prochlorococcus, a marine photosynthetic prokaryote of global significance. Microbiol Mol Biol Rev 63:106-127
Pawlik JR (1997) Fish predation on Caribbean reef sponges: an emerging perspective of chemical defenses. Proc 8th Int Coral Reef Symp 2:1255-1258

Pawlik JR (1998) Coral reef sponges: do predatory fishes affect their distribution? Limnol Oceanogr 43:1396-1399

Pawlik JR, Chanas B, Toonen RJ, Fenical W (1995) Defenses of Caribbean sponges against predatory reef fish. I. Chemical deterrency. Mar Ecol Prog Ser 127:183-194

Pile AJ (1997) Finding Reiswig's missing carbon: quantification of sponge feeding using dual-beam flow cytometry. Proc 8th Int Coral Reef Symp 2:1403-1410

Pile AJ, Patterson MR, Savarese M, Chernykh VI, Fialkov V (1997) Trophic effects of sponge feeding within Lake Baikal's littoral zone. 2. Sponge abundance, diet, feeding efficiency, and carbon flux. Limnol Oceanogr 42:178-184

Randall JE, Hartman WD (1968) Sponge-feeding fishes of the West Indies. Mar Biol 1:216-225

Reed J, Pomponi S (1997) Biodiversity and distribution of deep and shallow water sponges in the Bahamas. Proc 8th Int Coral Reef Symp 2:1387-1392

Reiswig HM (1973) Population dynamics of three Jamaican Demospongiae. Bull Mar Sci 23:191-226

Schmahl GP (1990) Community structure and ecology of sponges associated with four Southern Florida coral reefs. In: Rutzler K (ed) New perspectives in sponge biology, Smithsonian Institution Press, Washington, DC, p 384-390

Sokal RR, Rohlf FJ (1981) Biometry. The principles and practice of statistics in biology research, 2nd edn. WH Freeman \& Co, New York

Ting CS, Rocap G, King J, Chisholm S (2002) Cyanobacterial photosynthesis in the oceans: the origins and significance of divergent light harvesting strategies. Trends Microbiol 10:134-142

Verity PG, Robertson CY, Tronzo CR, Andrews MG, Nelson JR, Sieracki ME (1992) Relationship between cell volume and the carbon and nitrogen content of marine photosynthetic nanoplankton. Limnol Oceanogr 37:1434-1446

Widdows J, Johnson D (1988) Physiological energetics of Mytilus edulis: scope for growth. Mar Ecol Prog Ser 46: 113-121

Wilbur AE, Hilbish TJ (1989) Physiological energetics of the ribbed mussel Geukensia demissa (Dillwyn) in response to increased temperature. J Exp Mar Biol Ecol 131:161-170

Wilkinson CR (1983) Net primary productivity in coral reef sponges. Science 219:410-412

Wilkinson CR (1987) Interocean differences in size and nutrition of coral reef sponge populations. Science 236:1654-1657

Wilkinson CR, Cheshire AC (1990) Comparisons of sponge populations across the Barrier Reefs of Australia and Belize: evidence for higher productivity in the Caribbean. Mar Ecol Prog Ser 67:285-294

Witman JD, Leichter JJ, Genovese SJ, Brooks DA (1993) Pulsed phytoplankton supply to the rocky subtidal zone: influence of internal waves. Publ Proc Natl Acad Sci USA Nebraska Acad Sci 90:1686-1690

Witman JD, Patterson MR, Genovese SJ (2004) Benthicpelagic linkages in subtidal communities: influence of food subsidy by internal waves. In: Polis GA, Power ME, Huxel GR (eds) Food webs at the landscape level. University of Chicago Press, Chicago, IL, p 133-153

Wulff JL (1997) Parrotfish predation on cryptic sponges of Caribbean coral reefs. Mar Biol 129:41-52

Zamer WE, Shick JM (1987) Physiological energetics of the intertidal sea anemone Anthopleura elegantissima. II. Energy balance. Mar Biol 93:481-491 